\title{
Translating Lexical Legal Terms Between English and Arabic
}

\author{
Hanem El-Farahaty ${ }^{1,2}$
}

Published online: 26 February 2016

(C) The Author(s) 2016. This article is published with open access at Springerlink.com

\begin{abstract}
Legal translation between English and Arabic is under researched. However, the growing need for it, due to immigration and asylum seeking, among other reasons, necessitates the importance of more research. The asymmetry between English and Arabic poses many difficulties for legal translators, be they linguistic-based, culture-specific or system-based. The aim of this research is to discuss ways of translating lexical items between English and Arabic. In this current discussion I will present, exemplify and analyse the common difficult areas of translating English/Arabic legal texts and suggest ways of dealing with them. These areas involve culture-specific and system-based terms, archaic terms, specialised terms and doublets and triplets. With this aim in mind, the paper answers the following research questions:
\end{abstract}

1. What are the common difficulties of translating legal texts between English and Arabic?

2. What are the common lexical difficulties between English and Arabic legal texts?

3. What are the procedures of translating lexical legal terms between English and Arabic?

The paper concludes that translating the above-mentioned lexical terms requires expertise, professional training, robust knowledge of the linguistic and legal systems of languages, as well as up-to-date electronic dictionaries and well-defined parallel corpora.

Hanem El-Farahaty

h.el-farahaty@leeds.ac.uk

1 Centre for Translation Studies, Department of Arabic, Islamic and Middle Eastern Studies, University of Leeds, Leeds LS2 9JT, UK

2 Department of Foreign Languages, University of Mansoura, Mansoura, Egypt 
Keywords English/Arabic legal translation - English linguistics $\cdot$ Arabic linguistics · Lexical difficulties of legal translation · Legal systems

\section{Introduction}

Research on English-Arabic legal translation is scarce compared to research in the areas of English/Arabic translation. Research on English/Arabic legal translation focusses on the features of legal Arabic and the problems of translating Islamic terms. This paper is considered one of the fewest papers which were written about Arabic legal discourse back in 1989. He briefly discusses the features of Arabic legal discourse and its implications on legal translation. Alwazna [6] investigates the translation problems of the Hanbalī Sharī a Code from Arabic into English. In [7], he discusses the concept of how legal translation can correctly be tested in order to ensure precision and validity for application and implementation. Furthermore, he [8] discusses the strategies of legal translation with specific reference to the translation of Hooper's English translation of the Ottoman Majalla. El-Farahaty [18] analysed the features of English and Arabic legal discourse, with a focus on the similarities and differences between them. She also investigated the techniques of translating certain difficult areas with special reference to an authentic parallel legal corpus. Given the importance of this field and due to the increasing demand of English/Arabic legal translation, research on different aspects of legal translation between these two languages is needed. This paper stems from the pertinent need for more research that addresses this aspect of legal translation, i.e. translating legal terms between English and Arabic. With this aim in mind, the paper answers the following research questions:

1. What are the common difficulties of translating legal texts between English and Arabic?

2. What are the common lexical difficulties between English and Arabic legal texts?

3. What are the procedures of translating lexical legal terms between English and Arabic?

\section{Difficulties of Legal Translation: An Overview}

In legal translation, 'isomorphism' (i.e. one-to-one correspondence) [3, p. 182] is something unattainable and the possibility of creativity in translating legal documents is highly unlikely due to some constraints: (1) asymmetry of legal systems (2) incongruency of legal terminology and (3) legal cultural diversity [35, pp. 360-363]. The difficulties of legal translation include (1) the technical nature of legal language; (2) the specific nature of this technical language and (3) the legal language which is not a universal language but it is tied up with a national legal system [46, p. 203]. These constraints are particularly true in the case of translating between English and Arabic. 
Legal translation from English into Arabic or vice versa is even more difficult because of the wide gap between English and Arabic language systems, on the one hand, and legal systems, on the other. Both languages belong to different language families, Arabic being a Semitic language while English belongs to the IndoEuropean languages. Thus, translators from and into Arabic face difficulties on different linguistic levels, be they terminological (i.e. Sharīa Law vs Common Law terms), syntactic (i.e. modals and passive structures' incongruities), or textual (i.e. lexical repetition and punctuation marks).

The two legal systems are strikingly different and each of them is embedded in the cultural background of each system. Legal English is linked to Common Law where many 'terms of art' can only be understood against a Common Law background [39, p. 149] and they do not have a direct equivalent in either Islamic or Arab Civil Law. Legal Arabic, on the other hand, involves aspects of the Islamic Law and Civil Law. The former is followed in countries such as Saudi Arabia where the Qur'an and Prophetic tradition (Sunnah) form the basis of the constitution and therefore inform rulings in many aspects of life. Other countries, such as Egypt, follow both Islamic and Civil Law. Meaning and function of legal terms in each legal system are embedded in its legal culture. That is, the Common Law has its own way of legal classification; so that terms like 'lien' and 'pledge' are assigned separate legal meanings. The difference between these two terms is given below:

- In a lien, the lender can only detain the property/assets/goods until payments are made, and do not have the right to sell any such assets unless explicitly stated in the lien contract.

- In a pledge, the assets will have to be delivered by the pledger (borrower) to the pledgee (lender). The pledgee will have the legal title to the asset and has the right to sell the asset in the event that the borrower is unable to meet his obligations.

- http://www.differencebetween.com/difference-between-lien-and-vs-pledge/.

This difference in legal systems makes the task of the legal translator challenging because legal vocabulary is culture specific and system-bound. The legal translator's job then is not merely transcoding the legal meaning but transferring the legal effect.

This paper aims to present to legal translators from English into Arabic and vice versa the most common lexical difficulties that could arise due to the difference in the linguistic system or the culture-specific legal system. The paper attempts to offer guidance wherever possible on how to deal with them. With this aim in mind, the paper attempts to narrow the gap between research in Arabic legal translation and other languages. The data used for this paper includes extracts from authentic legal text types from Arabic and English and excerpts from the Leeds Arabic legal corpus available online.

\section{Lexical Difficulties}

Cao [10, p. 29] argues that 'the absence of equivalent terminology across different languages necessitates the constant comparison between the legal systems of the SL (source language) and TL (target language)'. Legal discourse is distinguished by its 
own 'legalese' [4, p. 14] and mixing between styles and registers makes the task of the translator unusually challenging. Examples of these involve the language of lay witnesses, slang of the police and technical jargon of the reports and testimony of expert witnesses who may be doctors, surgeons, bankers, technicians, etc. Some of the lexical difficulties whether language-specific or culture and system-specific that a translator of legal texts faces are discussed below:

\subsection{Archaic and Latin Terms}

In legal English, lawyers tend to use archaic terms such as 'hereby', 'thereby', 'aforesaid' and 'hereof'. These Old and Middle English words comprise a large part of the legal lexis [32, p. 13, 38, p. 87]. They continue to be used in the English legal documents, in spite of the claims that they are replaced by simpler English terms. One of the finest statements about this issue is given below:

Another misconception will be, since this text is 'legal' in nature, the translator with perfect justification puts on parade all those fancy 'legal expressions' he may have picked up here and there: 'herein-above'... before yielding to this temptation, he should first consult a recognized authority such as Driedger 'the Composition of Legislation'... He would be disappointed to learn that many of what once were regarded as sacred cows of legalese have long since fallen out of popular use, to be replaced by simpler words comprehensible to the man on the street. And why not? [33, p. 64]:

English 'is not one language, but two languages that happily live together under the same label, one is a Latin-root language and the other, a Germanic-root language' [3:185]. Legal English is also loaded with Latin terms that date back to the Middle Ages, such as 'ad hoc', 'de facto', 'pro rata', 'inter alia', 'ab initio' and 'mutatis mutandis' [27, p. 305].

Both archaic and Latin terms are elements of linguistic difference and they do not have a one-to-one correspondence in Arabic legal discourse. These require more effort on the part of the translator. Being a cultural mediator, the Arabic legal translator may try to understand Latin terms conceptually rather than translating them literally. The translator can also resort to glossaries to translate them into English, then explain, or expand them into Arabic [4, 43]. Below I will give a few examples to clarify this point:

Example 1

\begin{tabular}{|c|c|c|}
\hline ST & TT & Back translation \\
\hline $\begin{array}{l}\text { De facto } \\
\text { company }\end{array}$ & 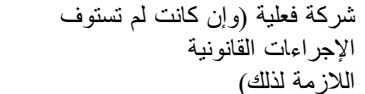 & $\begin{array}{l}\text { Actual Company (though did not meet the necessary legal } \\
\text { procedures for that). (Authors translation) }\end{array}$ \\
\hline
\end{tabular}

So, 'de facto' in a 'de facto company' means: existing or holding a specified position in fact but not necessarily by legal right' (Oxford Dictionaries online) and a 'de facto company' is rendered into Arabic in example one through explanation or explicitation. 
Translating archaic terms can also be done 'by having resort to parallel routines in the target language' [25, p. 394]. For example, 'notwithstanding' in English means 'despite' or 'although' [33, p. 64, [27], p. 50]. The Old English terms 'hereunder' and 'hereinafter' may be translated as (فيما يلي - which follows), 'thereafter' as (فيما بعد - after that). 'Set forth' in combination with 'herein' are rendered as (الواردة فيه - mentioned in it). 'Set forth' is also rendered in a different way in other contexts. In the Charter of the United Nations (ChUN, article 83:2), it is rendered as (المبينة - illustrated (mentioned)). In the Universal Declaration of Human Rights (UNHR, article 28), 'set forth' is rendered as: المنصوص عليها) mentioned). 'Foregoing' is rendered into (سالفة الذكر - aforementioned) in the (ChUN, article 77:2), by following the technique of 'structure shift' [11, p. 76] since an adverb is rendered as a phrase, i.e. idâfa construct. From the above examples, translation of archaic phrases into Arabic varies considerably and they can vary more in a sentence level context as given in example 2 below:

Example 2

\begin{tabular}{|c|c|c|}
\hline ST & TT & Back translation \\
\hline $\begin{array}{l}\text { A. I enclose herewith a detailed } \\
\text { report about the case }\end{array}$ & أرفق طِيه تقرير مفصل عن القضية: & $\begin{array}{l}\text { I attach to this a detailed report } \\
\text { about the case }\end{array}$ \\
\hline $\begin{array}{l}\text { B. In the presence of the two } \\
\text { witnesses hereinafter }\end{array}$ & في حضور الثاهدين التاليين: & $\begin{array}{l}\text { In the presence of the following two } \\
\text { witnesses: (Author's Translation) }\end{array}$ \\
\hline
\end{tabular}

These examples suggest that English archaic terms can be rendered into many nonarchaic or template terms in Arabic. Omission can also be used in translating archaic terms as they do not affect the meaning of the whole text. The term 'hereby' can be omitted in the Arabic translation of (I hereby declare ... أَعلن - I declare).

In translating such a varied lexical list of template phrases from Arabic into English, the task of the translator becomes relatively easier due to the existence of the corresponding archaic terms, so the translator tends to follow the norms in the target language, i.e. to use an archaic term in place of any Arabic template term or phrase. To clarify this idea, below are some examples from the Leeds Arabic legal corpus:

Example 3

\begin{tabular}{|c|c|}
\hline والجدة الذبر افتر الثروط قيده في & $\begin{array}{l}\text { In order for it to remain registered in the table, the aforementioned } \\
\text { conditions must be fulfilled (Author's Translation) }\end{array}$ \\
\hline $0 . / \mathrm{smlo}$ & gi-bin/showcontext.pl?cpos=LEGAL-AR2.4924683.4924683 \\
\hline
\end{tabular}


Example 4

\begin{tabular}{|c|c|}
\hline 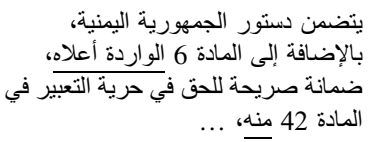 & $\begin{array}{l}\text { The Constitution of the Republic of Yemen includes, in } \\
\text { addition to Article } 6 \text { mentioned above, explicit } \\
\text { guarantee of the right to freedom of expression in Article } \\
42 \text { thereof... (Author's Translation) }\end{array}$ \\
\hline http://smlc09.leeds.ac.uk/cgi-bin & context.pl?cpos=LEGAL-AR2.666076.666076 \\
\hline
\end{tabular}

Example 5

\begin{tabular}{|c|c|}
\hline 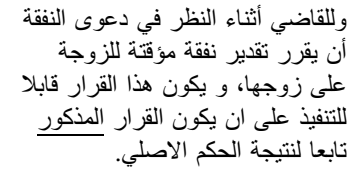 & $\begin{array}{l}\text { The judge, during the consideration of the alimony case, may } \\
\text { decide a temporary alimony estimate for the wife from her } \\
\text { husband. This decision will be enforceable given that } \\
\text { the above decision is a ramification of the original verdict } \\
\text { (Author's Translation) }\end{array}$ \\
\hline
\end{tabular}

Examples 3, 4 and 5 confirm what I have mentioned about the translator's resorting to 'parallel routines' in the target text where he/she tends to use an archaic term or phrase to reflect the formal nature of the legal text in translation than looking for a paraphrase or an explanation of the term in English.

\subsection{Terms of Art, General and Abstract Terms}

Legal English includes technical, that is legal terms, as well as non-technical, that is non-legal everyday vocabulary. The former category includes specialized legal terms which have fixed legal meanings and cannot be replaced by other words. Examples of these in the English tradition are 'common law' and 'equity' definitions of which are given below:

Common Law has various meanings: if contrasted with civil law, it covers the legal systems which are based on English law; if contrasted with equity, it means the set of rules developed by the court of Chancery; if contrasted with legislation, it means judge-made law [39, p. 176].

Equity is a set of rules developed by separate courts in England. It is important to know whether rights and remedies derive from equity or law because the requirements for and the legal consequences of the two are different [39, p. 150]. 
These are some of the available translations of these terms into Arabic:

\begin{tabular}{|c|c|c|}
\hline ST & TT & Back translation \\
\hline Common Law & 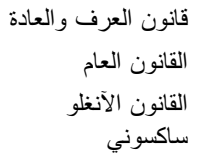 & $\begin{array}{l}\text { The Law of Customs and Habits } \\
\text { The General Law } \\
\text { The Anglo-Saxon's Law }\end{array}$ \\
\hline Equity & عدالة & Justice \\
\hline Equity Court & محكمة الإنصاف & The Court of Justice \\
\hline
\end{tabular}

The above translations are the literal rendering of the two terms, none of which offers a clear meaning of the term. Other suggestions of translations of 'Common Law’ could be (قانون الحالة - Case Law or القانون الوضعي - Statuary Law). To translate Common Law terms and other untranslatable English terms which express 'a unique legal concept' [14, p. 425] into Arabic, Alwazna [8, p. 242] suggests that the translator provides the transliteration of the SL term as well as the definition and an explanation of the term in question so as to familiarise the reader with the legal meaning of the term and the legal concept implied by the term concerned.

David [12, p. 65] also agrees with keeping the English term as there is no equivalent in Arabic legal systems that can convey the same meaning clearly. At times, 'the comparatist may resort to the methodological instruments of substitution and transposition, in order to find equivalents for untranslatable terms in his own legal terminology.' [14, p. 425]

In some cases, the translator may resort to 'functional adaptation' [31, p. 59]. For example, English distinguishes between a 'solicitor' and a 'barrister'. The former's work involves direct contact with clients and he/she can represent them through litigation, while the latter is an advocate who represents clients in the Crown (higher) court. Arabic does not distinguish between the two and uses one function for both of them, محامي) - lawyer). In this case, a functional adaptation of the term is important; hence 'barrister' can be translated as محامي في المحكمة العليا) - a lawyer in the Supreme Court). Another effective example in this context is the English legal term (Case Law - قانون الدعوى). Some translate it as قانون الحالة) - case law) while others translate it as اجتهاد قضائي) - Judicial diligence). The translation as it stands is not clear to the lay TL reader. To compensate for this lack of comprehension, a paraphrase of this term will ensure that the meaning of it is spread across borders:

\begin{tabular}{|c|c|c|}
\hline Term & Paraphrase & Back translation \\
\hline Case Law & 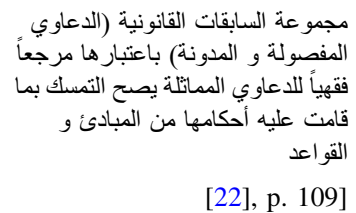 & $\begin{array}{l}\text { The group of previous legal cases (judged and } \\
\text { recorded) to be used as a jurisprudential reference } \\
\text { for similar cases in terms of the principles and } \\
\text { rules that these cases were based on } \\
\text { (Author's Translation) }\end{array}$ \\
\hline
\end{tabular}


Al-Qinai [5, p. 238] considers 'paraphrase' a good technique for rendering fixed legal terms into Arabic since they have no direct equivalents. He gives two examples from the English system: (Shadow Cabinet - الوزارة الظل), and (Party Whip which are subsequently paraphrased:

\begin{tabular}{|c|c|c|}
\hline Term & Paraphrase & Back translation \\
\hline Shadow cabinet & 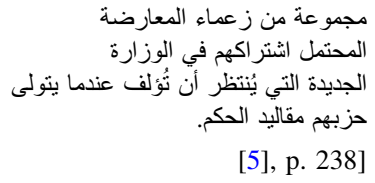 & $\begin{array}{l}\text { A group of opposition leaders who are likely } \\
\text { to take part in the new cabinet when their } \\
\text { party assumes power } \\
\text { (Author's Translation) }\end{array}$ \\
\hline Party whip & 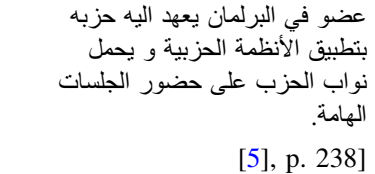 & $\begin{array}{l}\text { A member of the parliament who is given } \\
\text { the role, by his party, of applying party } \\
\text { regulations and asking the party members } \\
\text { of parliament to attend the important } \\
\text { sessions (Author's Translation) }\end{array}$ \\
\hline
\end{tabular}

Sometimes a translator can seek an approximate translation to give the nearest cultural equivalent of the original. For instance, the closest Arabic equivalent to 'Registry of Births and Deaths' or the 'Registry Office' is السجل المدني) - Civil Register).

Legal documents involve common terms with legal meaning such as 'distress, consideration, construction, redemption, tender, hold, and prefer,' [27, p. xvii] whose Arabic counterparts are subsequently given below:

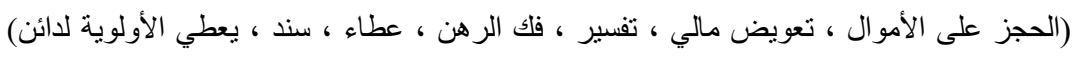

Because these common terms could have a specific legal meaning in a legal context, they require more effort and alertness on the part of the legal translator. An example of the above list is the term 'tender' which means in a legal context 'formally offer a plea or evidence, or money to discharge a debt.'

http://www.oxforddictionaries.com/definition/english/tender

In general English, it means 'soft', 'gentle', 'kind' or 'sensitive to pain or damage'. The translator, then, needs to consult specialists, and analyse similar texts for reaching the best solution. Another example is the term (compensation - تعويض), definitions of which in legal and non legal contexts are given below: 


\begin{tabular}{|c|c|c|}
\hline Aspect & Definition & Arabic translation \\
\hline 1 (Legal) & $\begin{array}{l}\text { Money that is paid to someone in exchange } \\
\text { for something that has been lost or } \\
\text { damaged or for some problem } \\
\text { Example: 'She received } £ 40,000 \text { in } \\
\text { compensation for a lost eye' } \\
\text { (http://dictionary.cambridge.org/dictionary/ } \\
\text { british/compensation) }\end{array}$ & 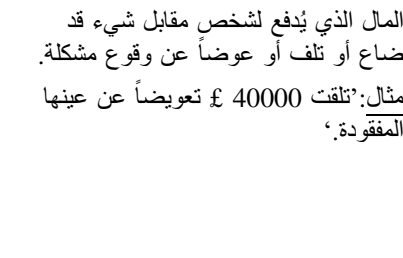 \\
\hline 2 (Abstract) & $\begin{array}{l}\text { Something that makes you feel better when } \\
\text { you have suffered something bad } \\
\text { Example: 'I have to spend three months of } \\
\text { the year away from home-but there are } \\
\text { compensations like the chance to meet } \\
\text { new people' } \\
\text { (http://dictionary.cambridge.org/dictionary/ } \\
\text { british/compensation) }\end{array}$ & 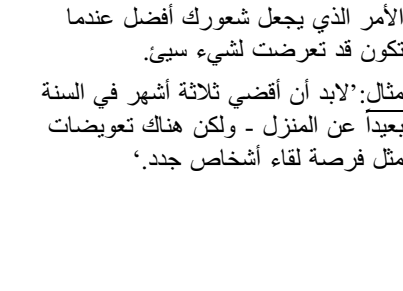 \\
\hline 3 (General) & $\begin{array}{l}\text { The combination of money and other } \\
\text { benefits (= rewards) that an employee } \\
\text { receives for doing their job: } \\
\text { Example 'Annual compensation for our } \\
\text { executives includes salary and bonus under } \\
\text { our incentive plan' } \\
\text { (http://dictionary.cambridge.org/dictionary/ } \\
\text { british/compensation) }\end{array}$ & 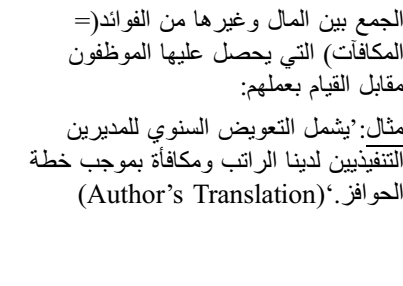 \\
\hline
\end{tabular}

As per the above definitions and examples, the term 'compensation' may mean financial or moral compensation. In a legal context, it is understood as (financial compensation - تعويض مالي) unless otherwise stated. In a non-legal context, it is understood as either abstract or benefits and awards. The abstract sense of the term could also be translated into Arabic as 'moral compensation' رد شرف), which means in English 'to give one's reputation back'.

Abstract terms are also crucial in the field of international law such as the human rights documents. Although the terms (freedom - الحرية, privacy - الخصوصية, right الحق and fundamental human rights - حقوق الإنسان الأساسية airness - الانصاف) are commonly used in our daily life, they are subject to many interpretations in the legal arena. The translator, then, must consider the differences of meanings that these terms may have in general and in a legal context [24, p. 116]. Phrases such as (reasonable steps - خطوات معقولة, reasonable measures - التدابير المعقولة reasonable

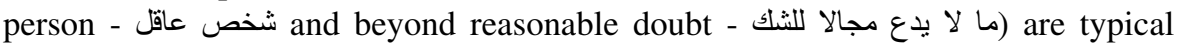
Common Law phrases, the translation of which into Sharīa Law or even into Civil Law can be misleading. The same is true for) fair and regular trial - محاكمة عادلة ونظامية). (Sufficient cause - سبب كاف) is another example of abstract words given by Engberg and Heller who comment on the indeterminacy of this expression: 'expressions like sufficient cause where the receiver does not know what criterion or scale is applied apart from the fact that the sender considers the case to be sufficient' [21, p. 146]. 
A legal translator is advised not to take the initiative towards disambiguating abstract words, translating them literally as they are and leaving the interpretations to the court. In Wai-Yee's view, 'descriptive equivalence' or 'paraphrase' is preferred 'if a one-to-one translation could not reveal the legal meaning or distinguish the legal term from other similar terms' [44, p. 79]. The strategy of 'paraphrase' shows that the concept is derived from a different legal system, the interpretation of which should be made according to this foreign legal system. An example from Sharīa Law can be the term ('iddah - the prescribed period of waiting for women to remarry, the length of which depends on whether her husband died, or she is divorced. Šarčević sees the above techniques as secure ways to compensate for terminological incongruity [35, p. 79]. Some subsidiary solutions for the lack of one-to-one correspondence between legal terms and expressions are given below:

- transcription, then paraphrase or footnote

- borrowing

- literal translation

- paraphrase

- neologism, if necessary in combination with explanatory footnotes. [45, p. 313, 14 , pp. 425-427, 15, pp. 86-72]

These techniques will be very helpful in translating culture-specific and systembased terms which are discussed in the following section.

\subsection{Culture-Specific and System-Based Terms}

Highly culture-bound texts, i.e. texts with references to a wide range of cultural patterns of the society in question, including aspects of economic, political and legal life, require a lot of background knowledge for a coherent interpretation... Concepts have meanings only by virtue of being embedded in socio-culturally determined frames which are more or less culture-specific' [36, pp. 133, 137].

Because there is no cultural equivalence, differences across legal cultures are more difficult to overcome than some of the issues discussed above. Legrand [30, p. 33] comments that 'every law remains an expression of the language, culture and tradition that called it into being ... there is nothing to show that the same inscribed words will necessarily generate the same idea in a different culture.' For SnellHornby [37, p. 34] 'translation is an imitation of the source text in the target text against the new cultural background, the main determinant of the translation being the specific function'. Accordingly, lexical items of different cultures may have different functions and meanings. Another example is the concept of (consideration - الاعتبار) in Common Law which does not exist in other laws, that is Civil Law. It is defined below:

Consideration is an essential element for the formation of a contract. It may consist of a promise to perform a desired act or a promise to refrain from doing 
an act that one is legally entitled to do. In a bilateral contract—an agreement by which both parties exchange mutual promises-each promise is regarded as sufficient consideration for the other. In a unilateral contract, an agreement by which one party makes a promise in exchange for the other's performance, the performance is consideration for the promise, while the promise is consideration for the performance...

http://legal-dictionary.thefreedictionary.com/consideration

Words can also be interpreted differently in the TL. For instance, reference to God can be interpreted differently in other cultures. To clarify this argument, the following example is cited on the effect of reference to God in the Spanish context:

The Spanish public servant is trying to calm down a Moroccan citizen who has just been caught with a large amount of hash. The public servant tells the Moroccan not to worry, that everything will turn out all right. The Moroccan replies "I believe in god". This answer when reproduced literally by the interpreter, offends the public servant who says to the interpreter: "Please tell him he is not the only one who believes in God and that I am no less a believer than he is. But if you really believe in God, you do not traffic in drugs." [41, p. 270]

The offence is caused because the interpretation of the sentence 'I believe in God' was received literally, taking no account of the underlying cultural element behind it. In the Arabic Culture, when a person is in trouble, a person may utter sentences like the one given above. That is why, 'legal translators must engage in a constant debate with the inherited meanings that are shaped through different habitus and forms of capital, in order to recover the discourse as completely as possible, bearing in mind the different value at play in any legal exchange' [41, p. 271].

Arabic official documents such as marriage or divorce certificates involve Islamic elements such as including the Hijri calender as well as the Gregorian calendar in certificates and contracts, reference to God at the beginning of the certificate such as the basmalla (بسم الله الرحمن الرحيم - in the name of Allah (God), the Merciful, the Compassionate); (الحمد لله - praise be to Allah (God)); (بعون الله تعالي.../ with the help of Allah (God)). Other documents refer to God and His Prophet (الحمد لله وحده والصلاة والسلام على من لا نبي بعده) Praise be to Allah (God), Prayer and Peace be upon the last of all the Prophets). Religious concluding remarks occur in the end of the document و الله ولي التوفيق) - May Allah (God) give success),

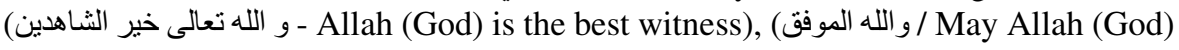
give success).

More examples of religious and culture-specific terms and phrases which occur in marriage contracts include (علي سنة الله ورسوله - according to the Sunnah of Allah (God) and his Messenger), (لاقدر الله - Allah (God) Forbids). Translation of these religious references such as the term (Allah/God) follows either 'foreignisation' or 'domestication' [40]. 'Omission' of other elements can also be an option such as the basmalla because they are not relevant to the target culture.

Some Arabic countries sometimes use other religious and culture-bound terms in Arabic legal texts such as referring to the time of the meeting by one of the five prayers that Muslims perform every day: المزمع عقده بعد مغرب يوم الثثلاثاء) - which will be 
held on Tuesday, after Maghreb (sunset) prayers) a religious concluding statement. If this text is to be translated to English, the translator should explain what he/she means by 'after Maghreb prayers'. That is, he/she may mention that this prayer happens after sunset, or it is an evening prayer. To be more precise, he/she adds in his translation the exact corresponding time of the meeting. In a Residential Lease Agreement, the ending time of the contract: 'and ending at $11.59 \mathrm{pm}$ on ...' is rendered into Arabic as:

$$
\text { 'و حتى الساعة 11:59 بعد الزوال من يوم...” نهار ا، }
$$

The translation of 'pm' is rendered as 'بعد الزوال - afternoon) which can be vaguely interpreted by those who are not aware of the prayer times and the connection between them and sun statuses. Thus, one can either expand the meaning below, or give the corresponding time (في منتصف النهار - midday):

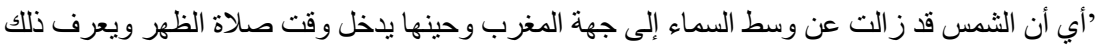

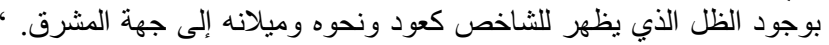

http://www.islamweb.net/ver2/fatwa/ShowFatwa.php?lang=a\&Id= $72447 \&$ Option=FatwaId

'That is, the sun has passed its zenith, in westerly direction, and at that time, the time for Zuhr (midday prayer) begins. The onlooker will observe his own shadow like a stick or similar inclining towards the East.' (Author's Translation)

The Arab reader finds the above expressions easy to understand because they are part of his/her culture. Yet, if they are translated into English, they will be meaningless to the TT, neither do they affect the validity of the document if it is to be considered legally binding. Possibilities of omitting these elements are stressed below:

...formulas of salutation referring to God are intertextual references, fully meaningful in the Arabic text, but this intertextuality is lost in non-Islamic cultures ... These ritual formulas do not have any relevance for the legal validity of the document; consequently, the possibility of omitting their translation remains open. [31, p. 21]

Aixela [2, p. 64] justifies the omission of culture-specific items in cases where they are either unacceptable in the target culture or irrelevant to the target reader or when the item in question is ambiguous. Aixela's viewpoint regarding the possibility of omitting items on the grounds of ambiguity, however, can be disputed here because is not the translator's task to deal with such ambiguity or omit them.

Sometimes, 'omission' (refer to [13] on the justifications of omissions) is used to overcome such religious elements as in translating Arabic multi-lateral treaties into English. To clarify this argument, Edzard [16, p. 38] has given some examples in Arabic treaties and in diplomatic correspondences of Arab leaders with the UN Secretary that are purely cultural. Examples of these include the concluding religious remarks (i.e. و الله أكبر - God is the greatest), reference to Qur'an and Sunnah, euphemisms (i.e. naval targets - أهداف بحرية), and catch phrases such as (اخوة عربية - Arabic Brotherhood). Edzard [16, p. 38] commented on the function 
of such religious forms as of 'demarcating function in addition to their overt religious stipulations'. In fact, being of a 'demarcating function', is true of Arabic documents, but it was not clearly identified what Edzard meant by such religious stipulations. He [17, p. 54] has also commented on the Arabic quotations from the Qur'an in the human rights documents as follows:

the function of the quotations is twofold: they can either be used to show an assumed equality between the Islamic and the Western Perspective on international human rights, or they can be used to show an assumed superiority of Islamic perspective.

The second possibility in Edward's view above is not likely because one can argue that quoting from the Qur'an is a cultural orientation. Thus, finding an alternative in the target culture that gives the same function of the source culture is the best solution. This strategy may be the most effective in literary translation or proverbs. In this context, Emery [20, p. 134] states that 'a problem of a different order stems from culture-bound expressions or formulas which are very much a part of everyday speech in Arabic and as such occur in literary texts. Here the translator is advised to choose a rendering which emphasizes the illocutionary force of the expression'.

In translating international documents such as those of the UN, there is a tendency to avoid religious terms. Edzard [16, p. 54] maintains that 'modern diplomatic Arabic still reflects a remarkable degree of historical, cultural and religious conscience that has no parallel in other official languages in the United Nations System'. Edzard [16, p. 55] argues that 'Arabic has fully adapted-where appropriate - to French-and English lexical and stylistic patterns. A high percentage of Arabic documents hardly reveal any Islamic background and could just as well be translations from English or French'. Edzard's conclusions, however, are based on the diplomatic texts - as he calls them-of the Arabic representatives in the UN not including any other Arabic documents.

There are numerous other examples of terms which are specific to Islamic Jurisprudence with no equivalence in English such as (- مُتععه - mut ${ }^{c}$ ah) and (عِّه - ciddah) (خُخ $/ \mathrm{kbhul}^{\mathrm{c}}$ - divorce). These terms can be translated by borrowing, i.e. transliterating them, as well as explaining, possibly in a form of a footnote. (مُنعهـ - mut ${ }^{\mathrm{c}}$ ah) literally means joy or delight, but in Islamic Jurisprudence it means 'temporary marriage (fixing dower and period)' [22, p. 297], (عِد/م/Ciddah) refers to the prescribed period of waiting for women before remarrying. These above terms are culturally loaded and need to be made more explicit. In this context, Hickey [29, p. 226] notes that 'the more weakly, invisibly or notionally the marking, the more the exegesis may be required to make the text suitable to be read by a TT reader.' Al-Khudrawi [1, p. 277] has defined and distinguished between two types of (عِّه - ciddah):

The term of probation incumbent upon a woman in consequence of dissolution of marriage either by divorce or the death of her husband. After a divorce the period is three months, and after the death of her husband, four months and ten 
days, both periods being enjoined by the Qur'an.'(For details of the exact time of 'iddah in the Qur'an refer to Sura 2, verses 232-234).

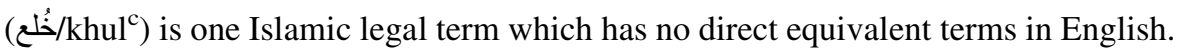
So, translating it as 'divorce' is not the straightforward equivalent of the Arabic terms. It can be translated in more than one way (i) coining an English equivalent 'women-sought divorce'; (ii) explicitation as 'divorce (of wife) for consideration payable by her' [22, p. 155]; (iii) explanation as given by Al-Khudrawi [1, p. 5:124]: 'an agreement concluded for the purpose of dissolving marriage. The release from the marriage tie obtained by a wife upon payment of a compensation or consideration whenever enmity takes place between husband and wife, and they both see reason to'. All these three methods could be equally combined with borrowing of the term to the TT, for 'clarifying these terms for readers with a different legal background to be able to grasp the meaning as accurately as possible from their viewpoint of the legal world [34, p. 362].

Concepts have meaning only by virtue of being embedded in socio-culturally determined frames which are more or less culture-specific and a message may be totally distorted if the implicit culture-specific information or culture-specific word meaning or an allusion is not grasped by the translator [36, p. 137]. Similarly, Legrand [30, p. 35] maintains that 'there is nothing to show that the same idea will necessarily generate the same idea in a different culture, a fortiori if the inscribed words are themselves different because they have been rendered in another language.'

Accordingly, translation of the above mentioned Islamic terms demands paraphrase to correspond directly and accurately to the SL word and render its connotations to the TL reader. This argument also applies to other terms such as:

الحد ، المبار اءه ، ناشزه

Below is the translation of the above terms as given in Al-Khudrawi [1, p. 88, 37, 420]:

Hadd: 'Prescribed punishment. In its primitive sense hadd signifies 'obstruction'. In law it expresses the punishments, the limits of which have been defined by Allah in the Qur'an or by Prophet Muhammad (P.B.U.H) in the 'Hadith' Traditions.

al-mubara'ah: 'mutual discharge'. A term used in the law of divorce when a man says to his wife, 'I am discharged from the marriage between you and me' and she consents there to. It is the same as $\mathrm{Khul}^{\mathrm{c}}$

nashizah: 'disobedient wife'. For a woman to be nashiz is to be described as 'wifely disobedient' who violates 'marital duties' on her part.

Alwazna [7, pp. 901-902] gives examples of Islamic Jurisprudence terms, mainly (bay c al-wafa'wa al-amanah/بيع الوفاء و الأمانة/ sale of faithfulness and honesty). In fact, Alwazna combined borrowing and paraphrase in the translation of such terms into English (for more examples on Islamic legal terms, refer to [6] and [7]). Descriptive paraphrase 'relays the intended legal meaning of the Islamic legal term 
and reproduces the intended legal effect thereof in the TT, which is the end result required in legal translation' [7, p. 903].

The variety of examples given in the above section show a number of procedures (refer to [43]) which a translator can use one or a combination of procedures to render these culture-specific terms that are alien to the target language, be them borrowing, literal translation, paraphrase or omission.

\subsubsection{Culture-Specific and System-Based Doublets and Triplets}

Doublets and triplets or binomials are 'a juxtaposition of two or may be three words' [38, p. 13] which 'are syntactically co-ordinated and semantically related' [26, p. 123] such as 'true, and correct'; 'false and untrue' or conjoined phrases: 'by and with the consent and advice of ...'. Arabic legal texts involve two or three words of related meanings, sometimes synonymous or near-synonymous which are conjoined by (g/wa - and) or (أو/aw - or). These are 'binomials or polynomials'; [9, p. 138] 'hendiadys' [5, p. 244]; 'synonym couplets' [42, p. 62] and 'dyadic couplets' by Koch [cf. 42, p. 62]. Doublets and triplets appear as part of legal Arabic as well as English. Some examples of Arabic-English doublets and triplets are given in the table below:

Examples 6, 7, and 8

\begin{tabular}{|c|c|}
\hline في حُفسخ هذا العقد فورا و تلقائيا و بدون تنبيه أو إنذار & $\begin{array}{l}\text { This contract revokes immediately without any prior } \\
\text { notice if ... (Author's Translation) }\end{array}$ \\
\hline 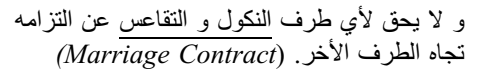 & $\begin{array}{l}\text { No Party is allowed to neglect or delay his commitment to } \\
\text { the other party. (Author's Translation) }\end{array}$ \\
\hline و و هو مصدق في قوله من جهة وجود العيب و التلف & $\begin{array}{l}\text { The Lessor is deemed to be trustworthy in his account of } \\
\text { the fault, the harm or the damage, and the cost of } \\
\text { repairing these ... Contract of Lease [28, pp. 186-187] }\end{array}$ \\
\hline
\end{tabular}

As shown above, doublets occur in two-word forms as in the first two examples or the three-word-forms in the final example. These terms recur in legal documents and the meaning of each term can have a particular legal implication, Sometimes the doublets are synonyms, but other times they are not and synonymy is problematic too as a concept. So translation of them should be done carefully. Translation of doublets and triplets in culture-specific and system-based documents such as marriage, divorce contracts as well as official documents vary. They can sometimes be literally rendered into the TT where repetition of the two terms happens as in the examples cited in [28]: 
Examples 9, 10, and 11

\begin{tabular}{|c|c|}
\hline 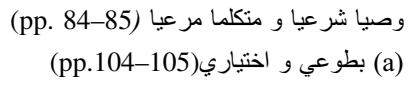 & $\begin{array}{l}\text { Legal guardian and competent spokesman } \\
\text { (a) Voluntarily and of my own free will, }\end{array}$ \\
\hline 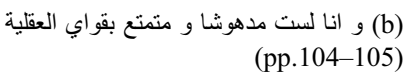 & (b) Being fully aware and of sound mind \\
\hline عصمتي و عقد نكاحي (99-98. pa) & My matrimonial authority and to my contract of marriage \\
\hline
\end{tabular}

In 9, 'a legal guardian' is supposed to be 'a spokesman' as well. In 10 (a) aطو (بطي و اختباري) can be rendered in one word either 'voluntarily' or 'of my own free will'. From a syntactic viewpoint, the translator must be mindful of the TL collocational preferences and attempt to reconcile these with transfer of the semantic value of the expression [20, p. 133]. For instance, in example 10 above, translating the prepositional phrase (بطوعي - literally: by my own volition) into an adverb 'voluntarily' shows a syntactic 'transposition' [43, p. 35] happened in the TT. In the second part of the doublet, a noun phrase (ختياري - literally: my choice) is 'shifted' [11, p. 74] to a prepositional phrase 'of my own free will'.

In 10 (b), (لست مدهوشا و متمتع بقواي العقلية literally: not absent-minded and enjoying my mental powers) both parts are the same and can be rendered by 'and of sound mind'. In this example, 'modulation' [43, p. 37] is employed in the translation of the negative clause لست مدهوشا - literally: not absent-minded) in Arabic into a TT positive clause 'being fully aware' with an addition of the adverb 'fully' that confirms the status of being aware.

In example 11, the doublet, (عصني و عقد نكاحي - literally: my bond of marriage and my contract of marriage), is rendered as 'my matrimonial authority and to my contract of marriage'. In Arabic, عصمة النكاح)) means 'the bond of marriage', and means 'married to someone, under someone's custody' [1, p. 286]. Thus, I believe, the first part of example 11 is best suited in this context and an omission of (عقد نكاحي - my contract of marriage) is justified.

Repetition in the rendition of doublets and triplets is sometimes needed because each of these terms has different legal implications as in the example below quoted in [28]

Example 12

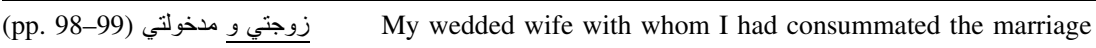

In the above example, rendition of the two terms (زوجتي و مدخولتي - my wedded wife) is important by means of 'expansion' [4, p. 184] of the second term (مدخولتي - with whom I have consummated marriage). Expansion explains further the legal implications of marriage in Islamic Law where a man can officially marry a woman, but still does not consummate marriage with her. 
In rare cases omissions in some of the doublets can also be justified because the two parts of the doublet mean the same as in the examples below cited in [28]:

Examples: 13, 14, and 15

\begin{tabular}{|c|c|}
\hline زوجتلك و أنكحتلك (87-86. pp) & $\begin{array}{l}\text { I have given you my daughter in marriage } \\
\text { (translation by omission) }\end{array}$ \\
\hline قبلت و رضيت بزواجها و نكاحها (87-86. pp) & $\begin{array}{l}\text { I accept your daughter in marriage } \\
\text { (translation by omission) }\end{array}$ \\
\hline المفقود الغائب (95-94. ph) & The missing person (translation by omission) \\
\hline
\end{tabular}

In example 13 above, the two terms (I have given you (second person singular) in marriage) are rendered into one term; and in 14, زو اجها و نكاحها) marriage (to her)) and (قبلت و رضيث - literally: accepted and agreed)—which is - المفقود الغائب) literally: the missing absent person) are rendered into one adjective 'the missing' with the addition of the noun 'person' as a substitution of the implicitly third person pronoun existing in the two words. This procedure of omission in translating doublets and triplets justifies translating doublets and triplets through 'simplification' [31, p. 97]. This argument is also supported below:

translating both words will flout the pragmatic maxim of quantity by making the target text unnecessarily verbose while dropping both will result in shorter but more implicit sentences. However, before embarking on either option, a translator has to determine which hendiadys achieves emphasis through repetition and which are simply superfluous. [5, p. 244]

Yet, the above argument is not always applicable as translators, clients, recipients and lawyers prefer to translate into the same number of words [31, p. 97]. This is motivated by the quest for accuracy through adherence to the ST.

In the following lines, I will consider the translation of English-Arabic doublets and triplets. By analysing these terms from both directions, I will be able to compare the procedures of translating them to their translation from Arabic to English. Below is example 16 from a 'lease agreement':

Example 16

\begin{tabular}{|c|c|c|c|}
\hline ST & TT & & Back translation \\
\hline $\begin{array}{l}\text { THIS LEASE AGREEMENT } \\
\text { made and entered into this } \\
\square \text { day of } \\
\end{array}$ & 20 & 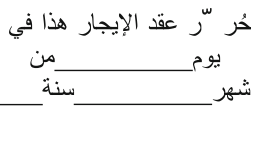 & $\begin{array}{l}\text { This tenancy contract was issued } \\
\text { on, } \\
\text { month } 20\end{array}$ \\
\hline
\end{tabular}

In the above example, the two synonyms (made and entered into-literally: (حُر مَر و بُدأ) this sentence 'this lease agreement was made and entered into' could be: 


$$
\text { تم تحرير و بدأ عقد الإيجار هذا.... }
$$

This tenancy agreement was issued and entered into .... (literal translation)

However, this translation is redundant and is not common in Arabic official documents. In Arabic, the contract becomes binding on the day it has been written or made. It is of value to the argument to refer to the definition of (حرَّر- to write) [23, p. 136]:

$$
\text { خحرَّر write, make (contract, etc.) }
$$

This verb is typical of legal Arabic discourse; it appears frequently in certificates, passports and it mostly occurs in the passive or the perfect.

\begin{tabular}{|c|c|}
\hline $\begin{array}{l}\text { Whereas Landlord desires to lease the Premises to Tenant } \\
\text { upon the terms and conditions as herein contained; } \\
\text { (Lease Agreement) }\end{array}$ & 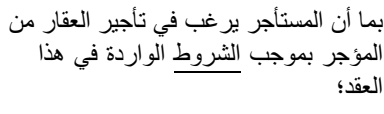 \\
\hline
\end{tabular}

Example 17

'Terms and conditions' are rendered into one word (الشروط - conditions) in example 17. (شرط - condition) can mean term or condition [23, p. 201] as given below:

شرط : condition, term, proviso, clause (for an agreement).

On the contrary, in an Account Opening Form, this doublet was rendered literally through the whole document into (الاحكام و الثروط - terms and conditions). It is safer to use different terms for this doublet because the legal implications of 'terms' may be different from that of 'conditions'. For example, terms for an employment contract include what have been agreed by the employer and the employee. Conditions, on the other hand in the same context mean the stipulations or requirements that are demanded by the employer from the employee.

Another example of doublets and triplets from the same document is given in 18 below:

\section{Example 18}

The standing instructions shall become null and void if the Account does not have sufficient balance to cover the transaction (Account Opening Form, article 2.5)
تعتبر التعليمات القائمة باطلة و لاغية اذا كان الرصيد

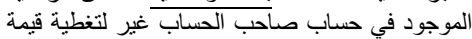
العملية.

As shown from the above excerpt, the doublet 'null and void' is rendered 'literally' into the same number of words: (باطلة و لاغية). The nullity of a contract or process leads to its nonexistence. This is explained by the translations of both words [23, p. 486 and 736 subsequently]: 
1. Null: منعدم ، لاغ ، باطة لونة (non-existent, void, null)

2. Void: باطل ، لاغ ، غير ملزم ، منعدم الاثر ، ليست له قوة قانونية (null, void, not binding, non non-existent, has no legal effect (null)) (back translations are mine).

The following are the equivalents of the Arabic word ( $\dot{\xi}$ - null/void) which apparently combines both the meaning of null and void:

$\dot{\xi} /$ null, null and void, naught, revoked, annulled, superseded (by promulgation of subsequent law) [23, p. 285]

One can also translate this doublet into Arabic by adding an intensifying adverb to give the meaning intended in the ST: (باطل قطعا - absolutely null). It is worth commenting that the translator has chosen to give a 'literal translation' to the English doublet to seek accuracy.

An example of triplets is 'I give, devise and bequeath all of my property' which can be translated as 'أعطي و أوصي وأورث كل تركتي'. This triplet is partly redundant because the meaning of the verb (أعطي - give) is included in the two verbs 'devise' and 'bequeath'. It could be better rendered as (أورث كل تركتي بوصية - I bequeath all of my property).

\section{Conclusion}

This paper has pinpointed the common sources of difficulty between English and Arabic from a terminological perspective. Asymmetry of the English and Arabic language and legal system result in many constraints facing the legal translators.

It is crucial that the legal translator should understand the different types of vocabulary he/she is dealing with in the text, whether they are common, specialised, archaic, abstract or functional. Each type of these lexical items requires caution, investigation and knowledge on the part of the translator. For example, with common words, the translator is entitled to distinguish the exact meaning of these words in the legal context. He/she should consult specialists and analyse similar texts for reaching the best solution. In the case of specialised terms, he/she may try to understand the lexical items conceptually rather than translating them literally, or could resort to specialist dictionaries. When translating archaic expressions, the translator should find an approximate corresponding expression in the TL or use paraphrasing. Abstract words are very sensitive and they are subject to many legal interpretations in the legal context. Thus, the legal translator should translate them literally and should not try to disambiguate them even if this translation will result in a vague text.

In translating religious and culture-based terms in the documents, translators could employ different techniques such as 'expansion, adaptation, transposition, and structure shift'. From Arabic into English, I have noticed that documents that are subject to Sharîa Law use certain religious formulas such as the basmalla and other references to God. These formulas are translated through 'domestication' of the term 'Allah' to correspond to 'God' in the TT. 
Translation of doublets and triplets vary. They could be rendered into one element in the TT where the translator views these as rewording of the same linguistic meaning and/or the cultural concept, hence decides to be economic in translating them. One can also argue that the 'literal translation' technique, where there is a repetition in translating some doublets, is sometimes unjustified where one TT equivalent can render the intended meaning given in the original. In most of the examples presented, doublets, and triplets are rendered in the same number of words in the TT even though they result in redundancy. Thus, 'literal translation', and sometimes 'transposition' are the most common techniques of translating doublets and triplets.

Open Access This article is distributed under the terms of the Creative Commons Attribution 4.0 International License (http://creativecommons.org/licenses/by/4.0/), which permits unrestricted use, distribution, and reproduction in any medium, provided you give appropriate credit to the original author(s) and the source, provide a link to the Creative Commons license, and indicate if changes were made.

\section{References}

1. Al-Khudrawi, Deeb. 1995. A dictionary of islamic terms. Beirut/Damascus: Alyamamah for Printing and Publishing.

2. Aixela, J. 1996. Culture specific items in translation. In Translation, power, subversion, ed. R. Alvarez, and M.C. Vidal, 52-78. Clevendon: Multilingual Matters.

3. Alcaraz Varó, Enrique. 2009. Isomorphism and anisomorphism in the translation of legal texts. In Translation issues in language and law, ed. F. Olson, R.A. Lorz, and D. Stein, 182-192. UK: Palgrave Macmillan.

4. Alcaraz Varó, Enrique, and Brian Hughes. 2002. Translation practices explained, legal translation explained. Manchester: St. Jerome.

5. Al-Qinai, Jamal. 1999. Explication vs. Implication in English-Arabic translation. Theoretical Linguistics 25: 235-255.

6. Alwazna, R.Y. 2013. Translating Hanbali Sharī'a code from Arabic into English. Deutschland: LAP LAMBERT Academic Publishing.

7. Alwazna, R.Y. 2013. Testing the precision of legal translation: The case of translating islamic legal terms into English. International Journal for Semiotics of the Law 26(4): 897-907.

8. Alwazna, R.Y. 2014. Important translation strategies used in legal translation: examples of Hooper's translation of the Ottoman Majalla into English. In The Ashgate handbook of legal translation, ed. L. Cheng, K. Sin, and A. Wagner, 237-254. Surrey: Ashgate Publishing Limited.

9. Badawi, E., M.G. Carter, and A. Gully. 2004. Modern standard Arabic: A comprehensive grammar. London/New York: Routledge.

10. Cao, Deborah. 2007. Translating law. Clevedon: Multilingual Matters.

11. Catford, J.C. 1965. A linguistic theory in translation: An essay in applied linguistics. Oxford: Oxford University Press.

12. David, R. 1980. English law and French law. London: Stevens.

13. Davies, Eirlys E. 2007. Leaving it out: On some justifications for the use of omission in translation. Babel 53(1): 56-77.

14. de Groot, Gerard-René. 2006. Legal translation. In Elgar encyclopaedia of comparative law, ed. J. Smiths, 423-433. Cheltenham: EE Publishing.

15. de Groot, Gerard-René, and Conrad J.P. van Laer. 2006. The dubious quality of legal dictionaries. International Journal of Legal Information 34(1): 46-86.

16. Edzard, Lutz. 1996. Stylistic elements in the use of Arabic as language of diplomacy: Recent developments in United Nations context. Die Welt des Islams 36(1): 25-58.

17. Edzard, Lutz. 1998. Language as a medium of legal norms. Implications of the use of Arabic as a language in the United Nations system. Berlin: Duncker \& Humblot.

18. El-Farahaty, Hanem. 2015. Arabic-English-Arabic legal translation. London/NewYork: Routledge. 
19. Emery, Peter G. 1989. Legal Arabic texts: Implications for translation. Babel 35: 1-11.

20. Emery, Peter G. 1990. Lexical incongruence in Arabic-English translation. Babel 37(3): 129-137.

21. Engberg, Jan, and Dorothee Heller. 2008. Vagueness and indeterminacy in law. In Legal discourse across culture and systems, ed. V.K. Bhatia, Christopher N. Candalin, and Jan Engberg, 145-162. Hong Kong: Hong Kong University Press.

22. Faruqi, Harith S. 1983. Faruqi's law dictionary: Arabic-English. Beirut: Librairie du Liban Publishers.

23. Faruqi, Harith S. 2008. Faruqi's law dictionary: English-Arabic. Beirut: Librairie du Liban Publishers.

24. Garre, Marianne. 1999. Human rights in translation: Legal concepts in different languages. Denmark: Copenhagen Business School Press.

25. Garzone, Giuliana. 1999. The translation of legal texts. A functional approach in a pragmatic perspective. Textus 12(2): 391-408.

26. Gustafsson, Marita. 2009. The syntactic features of binomial expressions in legal English. Text and Talk - Interdisciplinary Journal for the Study of Discourse 4(1-3): 123-142. doi:10.1515/text.1.1984. 4.1-3.123.

27. Haigh, Rupert. 2004. Legal English. London: Cavendish Publishing.

28. Hatim, B., A. Shunnaq, and R. Buckley. 1995. The legal translator at work: A practical guide. Jordan: Dar Al-Hilal.

29. Hickey, Leo. 1998. The pragmatics of translation. Clevedon: Multilingual Matters.

30. Legrand, Pierre. 2005. Issues in the translatability of law. In Nation language, and the ethics of translation, ed. S. Berman, and M. Wood, 30-50. UK: Princeton University Press.

31. Mayoral Asensio, Roberto. 2003. Translating official documents. Manchester: St. Jerome.

32. Mellinkoff, David. 1963. The language of the law. Boston: Little/Brown.

33. Meredith, Clive R. 1979. Some notes on legal English. Meta 24(1): 54-67.

34. Pommer, Sieglinde E. 2008. No creativity in legal translation. Babel 54(4): 355-368.

35. Šarčević, Susan. 1997. New approach to legal translation. London: Kluwer Law International.

36. Schäffner, Christina. 1997. Strategies of translating political texts. In Text typology and translation, ed. A. Trosborg, 119-144. Amsterdam: John Benjamins Publishing Company.

37. Snell-Hornby, M. 1988. Translation studies: An integrated approach. Amsterdam: John Benjamins.

38. Tiersma, Peter m. 1999. Legal language. USA: University of Chicago Press.

39. Triebel, Volker. 2009. Pitfalls of English as a contract language. In Translation issues in language and law, ed. F. Olson, R.A. Lorz, and D. Stein, 147-181. UK: Palgrave Macmillan.

40. Venuti, L. 1995. The translator's invisibility: A history of translation. London: Routledge.

41. Vidal Claramonte, M., and Africa Carmen. 2005. Re-presenting the 'real' Pierre Bourdieu and legal translation. The Translator 11(2): 259-275.

42. Williams, M. P. 1989. A comparison of the textual structures of Arabic and English written texts: A study in the comparative orality of Arabic. Unpublished Ph.D. thesis, University of Leeds.

43. Vinay, Jean-Paul, and Jean Darbelnet. 1995. Comparative stylistics of French and English: A methodology for translation. Amsterdam: John Benjamins.

44. Wai-Yee, Poon E. 2002. The pitfalls of linguistic equivalence: The challenge for legal translation. Target 14(1): 75-106.

45. Wai-Yee, Poon E. 2005. The cultural transfer in legal translation. International Journal for Semiotics of the Law 18: 307-323.

46. Weisflog, W. E. 1987. Problems of legal translation. Swiss reports presented at the XIIth international congress of comparative law, 179-218. Zurich: Schultthess.

\section{Online references}

47. Islamweb [online]. http://www.islamweb.net. Accessed on February 2015.

48. Cambridge Dictionary: [online]. http://dictionary.cambridge.org. Accessed on 15 April 2015.

49. Leeds Arabic Legal Corpus: [online]. http://smlc09.1eeds.ac.uk. Accessed on 21 May 204.

50. Oxford Dictionaries [online]. http://www.oxforddictionaries.com. Accessed on 13 September 2014.

51. The Free Dictionary: [online]. http://legal-dictionary.thefreedictionary.com/consideration. Accessed on 16 April 2015. 